\title{
Charges fly in \$1bn hormone patent battle
}

[SAN FRANCISCO] Nine years of legal conflict came to a head this week as a jury began its deliberations at the end of a six-week trial to decide whether Genentech Inc. infringed a University of California patent for DNA for human growth hormone.

The trial, in federal court, has included testimony of a midnight raid 20 years ago to take DNA from a lab at the University of California at San Francisco (UCSF), allegations that at least one of the world's leading molecular biologists has been lying under oath, and charges that a key paper published in Nature in 1979 included false information, even though its conclusions remain valid.

In the lawsuit, filed in 1990, the university contends that Genentech used its patented DNA to perform experiments in spring 1979 that led to the creation of Genentech's blockbuster drug Protropin, a synthetic hormone used to treat growth disorders.

For this alleged infringement, the university is seeking $\$ 400$ million in back royalties and interest. It is also asking the judge to triple that amount to $\$ 1.2$ billion because of alleged wilful misconduct by Genentech.

If the jury finds in favour of the university, Genentech is likely to appeal, and the impact of any monetary judgement may be years away. But such a verdict would have a far greater psychological effect, as it would mean that what is arguably the most successful biotechnology firm of the genetic engineering revolution prospered because of misappropriated material.

Genentech executives deny any patent infringement, saying that its scientists constructed the DNA for human growth hormone independently in 1979, and that this was the DNA that was used in bacterial synthesis to create Protropin.

The trial has pitted former colleagues against each other. As Joseph F. Sambrook, director of research at the Peter MacCallum Cancer Institute in Melbourne, Australia, and an expert witness for the university, told

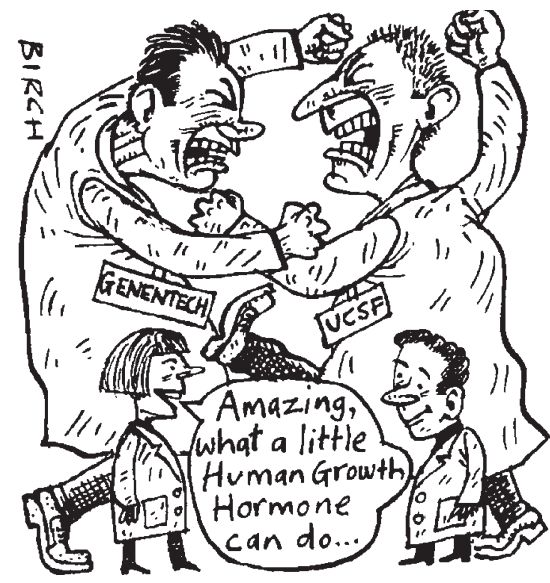

the jury: "Someone isn't telling the truth."

The most dramatic testimony involved Peter H. Seeburg, a former researcher at UCSF and Genentech who is now director of the Max Planck Institute for Medical Research in Germany, and David V. Goeddel, a former Genentech scientist who is now chief executive at Tularik Inc., a biotech company in South San Francisco. Seeburg described how, just before midnight on 31 December 1978, shortly after he left UCSF for Genentech, he slipped into the university, removed a sample of human growth hormone DNA from a lab, and took it to Genentech.

Genentech attorneys reluctantly acknowledged during the trial that Seeburg brought the UCSF material to the firm, but insist that it was not used to produce the hormone drug. After refusing repeated requests by the university to return the sample in 1979 , Genentech paid the university $\$ 2$ million then to settle the dispute.

Seeburg told the court that this purloined material was used in spring 1979 to help Genentech develop the bacterial synthesis process used to produce Protropin (see pages 297-298). Seeburg and Goeddel were Genentech's lead investigators on the project at the time.

But Goeddel, along with other Genen-
In a letter to Nature (see pages 297-298), current and former researchers at Genentech say that they "categorically deny" accusations by their former colleague, Peter Seeburg, that data on the sequencing of a gene for human growth hormone published in a key paper in the journal in 1979 (see Nature 281, 544-548; 1979) were false, "and that he knew they were false when
the paper was submitted". In response, Seeburg repeats an admission made during recent court proceedings (see above) that the work made use of a cDNA clone that had originated at the University of California, San Francisco, and writes "I deeply regret that, contrary to the principles of scientific endeavour, the Nature paper contains a technical inaccuracy".
The Genentech authors, who were the co-authors of the original paper and say that they stand by its content, say that Seeburg is being "intellectually dishonest" in claiming that it is permissible to make up data on the basis of "similar work", and in describing a non-existent plasmid as a "technical inaccuracy". Seeburg says "all scientific conclusions of the paper are correct".

tech colleagues, argues that the DNA from UCSF was not part of the landmark Genentech experiments in which Escherichia coli bacteria were genetically engineered to produce the synthetic growth hormone.

Seeburg maintained during the trial that he and Goeddel had a pact never to reveal the use of UCSF's DNA. But after years of silence and walking what Seeburg described as "a tightrope" during pre-trial depositions, he finally admitted to using it.

The trial audience was stunned when Seeburg testified that the Nature paper (Nature $281,544-548$; 1979) contained a number of "technical inaccuracies", including an outright falsehood, namely that a key plasmid used for the bacterial synthesis "did not exist".

Seeburg testified that the UCSF DNA was used instead, but was not referred to in the Nature paper because of the potential legal implications. He also said that an entire figure purporting to reflect the sequence of the Genentech human growth hormone DNA was a copy of the sequence of the UCSF DNA.

Genentech attorneys and Goeddel deny Seeburg's statements, with the lawyers challenging Seeburg's motives. The university licensed its patent for human growth hormone to Eli Lilly \& Co. If the university is successful in its lawsuit against Genentech, Seeburg stands to earn nearly 10 per cent of recovered royalties, as he is a co-inventor of UCSF's human growth hormone DNA.

Genentech's attorneys also challenged Seeburg's character, saying his acknowledged problems with cocaine and alcohol during his early years at Genentech raise further questions about his veracity.

Scrutiny of 20-year-old Genentech notebooks of the critical experiments in 1979 was a crucial component of the case, with opposing sides interpreting the documents differently. None of Seeburg's notebooks was produced at the trial, but those of Goeddel and other Genentech researchers were.

Sambrook testified that his analysis of the notebooks and key experiments suggested that Goeddel and a research associate could not have completed the DNA experiments on the day in May 1979 entered in the notebooks, as there was not sufficient time in the day to complete the experiments in question.

Genentech attorneys dispute this, but one of Genentech's own experts, Judith L. Campbell, a professor of chemistry and biology at the California Institute of Technology, acknowledged under cross-examination that the notebooks did not prove that Genentech independently developed the DNA used in the experiments.

Campbell acknowledged there were "errors" in the Nature paper, parts of which she agreed were "misleading" or not supported by Genentech lab notebooks. Rex Dalton 